DEVELOPING WRITING MATERIALS IN DESCRPTIVE TEXT THROUGH FACEBOOK GROUP FOR EIGHT GRADE SMP SWASTA JAMBI MEDAN

AN ARTICLE

Submitted in Partial Fulfillment of the Requirements for the Degree of Sarjana Pendidikan

BY:

RONATAMA SARI NABABAN

Registration Number: 2161121037

ENGLISH AND LITERATURE DEPARTMENT

FACULTY OF LANGUAGES AND ARTS

UNIVERSITAS NEGERI MEDAN

2021 


\title{
TEACHER TALK CATEGORY IN FLINT USED BY ENGLISH TEACHER AT SMA YPK MEDAN
}

*Ronatama Sari Nababan

** Prof. Dr. Sumarsih, M.Pd.

\begin{abstract}
Ronatama Sari Nababan. 2161121037. Developing Writing Materials in Descriptive Text through Facebook Group for Eight Grade SMP Swasta Jambi Medan. A Thesis. Faculty of Languages and Arts, Universitas Negeri Medan. 2021.
\end{abstract}

This research deals with developing writing materials about descriptive text through facebook group for eight grade junior high school. The research was conducted to examine the initial condition of students before using the descriptive text materials developed through FB and to develop the materials through FB for the teaching descriptive text. This research was conducted at SMP Swasta Jambi Medan. This research was conducted by using Research and Development design through six stages; gathering information and data, analyzing data, developing materials and media, validating by expert, revising, and final product. The subject of this research was eight grade of SMP Swasta Jambi Medan. The data were gathered by reviewing documents, conducting interview to English Teacher, and distributing questioner to eight grade consist of 26 students to get the students' need. The interview and questioner result prove that the students need interesting materials about descriptive text and media. The developed writing materials was validated by expert which average score 3,5 show that the writing materials are valid and suitable to use for grade eight SMP Swasta Jambi Medan. The result of the product distributed to the students through Facebook.

Key words: Development, Writing Materials, Facebook.

\footnotetext{
*Graduate Status

** Lecturer
} 


\section{INTRODUCTION}

Background of Study

Writing is a matter that expresses ideas or thoughts in a piece of writing. Alika, Usman, Hastini (2016:2) "Writing is the land of expression. Through writing students can express their ideas, their feelings, their hopes, and etc." As Nunan (in Basonggo, Said, Dewi, 2016) stated that, "writing is the process of thinking to invent ideas, thinking about how to express into good writing, and arranging the ideas into statements and paragraphs clearly". This shows that students are expected to explore ideas and make good paragraphs into writing

The material is one to improve students' writing abilities. So the teacher's role before teaching material must first prepare the material to be taught. The use of appropriate materials will help students learn to write in a good way. In the teaching-learning process, teachers must develop materials that are appropriate for students to encourage them to improve their writing skills. The teacher plays an important role as a facilitator, so that a teacher must be able to use the media and technology that is currently developing to assist students in using media and technology in the process of learning activities.

Social networking sites are now quickly becoming ubiquitous online. In the current era, online sites are now very popular among schools and teachers and students. One of the most commonly used online sites is Facebook (FB). This site can be one of the online learning media that can be used by teachers. Through this FB students can develop their interests and skills specifically in writing.

Researchers' results from preliminary data found that the most serious problems faced by students were writing difficulties due to lack of vocabulary, making it difficult for them to identify new words from a text and interpret it. It is also continuous when they are not able to develop their ideas in writing a text. Students who have minimal vocabulary will feel confused to start their writing and in the middle of writing they do not know what they have to do to continue. So students are often stuck in the middle of their writing. Besides the difficulty of students in writing is students are still confused using the right grammar and writing good cohesion and coherence so that students become confused with the use of conjunctions in preparing sentences and paragraphs.

So in the teaching-learning process, teachers need to develop materials and provide appropriate media and technology for students. By developing learning materials and 
media, it is expected to improve students' writing abilities. One of the learning media that can be used by teachers is the FB website. Then the researcher will develop descriptive material and will apply it to the FB so that students will be more interested in learning descriptive text.

Therefore, it is necessary to provide suitable and interesting material for eighth grade students of Medan Jambi Private Junior High School to encourage them to practice writing. For the reasons above, researchers are interested in Developing Writing Materials in Descriptive Text through FB Group for Eight Grade SMP Swasta Jambi Medan. Researchers will create a FB group as a medium for student learning and from that group researchers will hold discussions, share material and practice the students' ability to write through exercises that will be shared within the FB group.

\section{REVIEW OF LITERATURE}

\subsection{Writing Skill}

\subsubsection{Definition of Writing}

According to Alika, Usman, Hastini (2016:2) "Writing is the land of expression. Through writing students can express their ideas, their feelings, their hopes, and etc." Nunan (in Basonggo, Said, and Dewi, 2016) stated that, "writing is the process of thinking to invent ideas, thinking about how to express into good writing, and arranging the ideas into statements and paragraphs clearly". In conclusion, writing is the process of expressing ideas or arguing into writing that produces a product where the product is addressed to the reader.

\subsubsection{Characteristics of Writing}

There are some characteristics of written language according to Brown (2000: 341). They are:

$\begin{array}{lll}\text {-Permanence } & \text {-Production time } & \text { Distance } \\ \text {-Orthography } & \text {-Complexity } & \\ \text {-Vocabular } & \text {-Formality } & \end{array}$

\subsection{Teaching writing}

Richard and Renandya (in Dani 2014) stated that writing process as approval activity may be broadly seen as comprising four main stages: planning, drafting, revising, and 
editing. Before starting to write a paragraph there are some steps: pre-writing, drafting, revising, and editing those steps will help to make a better writing.

\subsection{Curriculum 2013 (K-13)}

Khasanah (2015) state that Curriculum is a basis of teaching-learning process, so every teaching-learning process has to follow the curriculum. It is the planned interaction of pupils with instructional content, materials, resources, and processes for evaluating the attainment of educational objectives. That is why every teacher has to understand and follow the current curriculum before planning and developing a kind of teaching-learning process and the materials for the teachinglearning process.

\subsection{Descriptive text}

Descriptive paragraph is a paragraph that describes something in details. Peter and Megan state that describing have grammatical features and they state also that descriptive paragraph is a form of writing that talks about describing person, thing, animal, events, object or certain place in vivid detail which has generic structure; identification, description, and conclusion (optional).

\subsection{Developing material}

Jolly and Bolitho in Tomlinson (2013: 97) propose some steps that should be followed in developing writing materials. Those are:

a. Identification of need for materials

b. Exploration of need

c. Contextual realisation of materials

d. Pedagogical realisation of materials

e. Production of materials

f. Student use of materials $\backslash$

\subsubsection{Developing Materials Through Facebook (FB) for Teaching Descriptive Text}

Learning English is very boring and difficult for some students. This is because English teaching is too monotonous and makes students bored. Besides that the motivation of students to learn English is also less so that makes students less interested in learning English. In this study, researchers will develop English material, especially descriptive text, and then use the FB application as a media for sharing material. FB application users can join similar groups of people with the same interests, receive and update news and share information. By this application the teacher will be forms a class 
group, divides the material in groups and directs students involved in the process of learning activities, especially about descriptive text material that focuses on writing skills. Through this way of learning students will be more motivated to learn descriptive text because in this FB group the teacher can provide material in the form of pictures, videos, and also text.

\section{RESEARCH METHODOLOGY}

\section{Research Design}

This research was conducted by using development research. It was adopted the R\&D research methodology by Borg and Gall (2003) who stated the educational R\&D is an industry- based development model in which the findings of the research are use to design new product and procedures, which systematically field-tested, evaluated, and refined to meet the specified criteria of effectiveness, quality or similar standards stated by Borg and Gall (2003: 596) that the research findings were used to develop new product and procedures.

\section{Instrument of Collecting Data}

The instrument of collecting data that had been used in this research were observation, interview, and questionnaire.

\section{The Subject of Research}

The subjects of this research was the students of eight grade of SMP Swasta Jambi Medan.

\section{The Technique of Collecting Data}

Data is collected as follow:

1. The researcher had been done observation to know the syllabus and existing materials.

2. The researcher had been interviewed to the English teacher for knowing the student's competence in writing and their problem in learning English. Beside that, the researcher will be interviewed some students to know their need in English learning, particularly in writing descriptive text.

3. The researcher had been given the questionnaires to the students. In this stages, the question are given consist of the questions to know the student's 
interest in learning English, especially in writing descriptive text and the problem in learning.

\section{The Techniques of Analyzing data}

Analyzing the questionnaires and interview result. The questionnaires were administrated to the students to get the related data. Interview had been administrated to the English teacher to supporting the questionnaire. Then, the data had been tabulated in order to obtain the best solution in terms of preparing what were the appropriate materials for the students in SMP Swasta Jambi Medan.

\section{The Procedures of Writing Materials and Media Development}

By adapting the small-scale R\&D Project proposed by Borg and Gall

1. Gathering data and Information

2. Need Analysis

3. Designing Materials

4. Validating by The Expert

5. Revising

6. Final Product

\section{RESEARCH RESULT AND DISCUSSION}

\section{A. Research Result}

\section{Gathering Data and Information}

The data and information were derived from observing, reviewing documents and interviewing teacher before doing research. The researcher did the observation on November 11 in SMP Swasta Jambi Medan, based on the reviewing documents (syllabus, textbook), the basic competence in syllabus stated that the grade eighth students had to be able to express the meaning and steps of rhetoric in a simple short essay by using a variety of written language accurately, fluently and acceptably to interact with the environment in descriptive.Then the researcher found that the teacher used descriptive writing materials only from textbooks, after examining the text and assignments the researcher found that in this book there were only texts, practice questions and assignments that made students confused and uninterested in writing.

After reviewing the documents, researcher also got information from interviewing teacher, based on interview teacher said that teaching writing usually done after 1 till 2 times meeting, it depends on the class. While teaching writing teacher faced that the materials in the textbook were not interesting for students, students were bored and 
students were not interested with the writing text in textbook. Teacher also said that the writing materials in the textbook were not enough to fulfil students' needs, which is it should hone students' critical thinking, vocabulary and writing.

\section{The Result of Needs Analysis}

\section{a. Target Needs}

\section{1) Necessities}

For the necessities, there were $65.4 \%$ of the students that chose the skill that they need in writing a text which was using the suitable structure and words choice. The second skill chosen by $30.8 \%$ of them that they need was to use the correct and appropriate grammar in writing a text. There were $15.4 \%$ of the students who chose expressing ideas into some different sentences and $11.5 \%$ students who chose arranging text use the correct structure of the text as their necessity. There were $7.7 \%$ of the students chose arranging the appropriate sentences based on the function each text.

\section{2) Lacks}

In writing a text, the difficulties faced by $42.3 \%$ of the students were related to the use of grammar. The second difficulties faced by $26.9 \%$ of the students had difficulties formulating sentences based on the function each text. The third difficulties faced by $19.2 \%$ of the students had difficulties in selecting the appropriate word choice .

\section{3) Wants}

For students' wants, most of the students wanted to increase the ability in writing English. The students who want to be able to master vocabulary were $26.9 \%$. There were $23.1 \%$ of the students who want to increase their knowledge of text type. There were $15.4 \%$ of them wanted to use the suitable vocabularies in writing texts. To accumulate the students' want, some activities will be given that cover the use of text type, grammar, and conjunction.

\section{b. Learning Needs \\ 1) Input}

For material input, there were $76.9 \%$ of students wanted the material input was picture, $26.9 \%$ of them chose text, and $15.4 \%$ of them chose video.

\section{2) Procedure}

There were $61.5 \%$ of the students wanted to write text by given the 
topic. $23.1 \%$ of them choose to free writing and writing text from the picture.

There were $3.8 \%$ of them choose to writing with questions as guide.

\section{3) Setting}

In doing writing activity, most of the students wanted to do in individually about $57.7 \%$.

\section{4) Teacher and Learner Roles}

\section{a) Learners' Role}

In doing writing activity, the students around $69.2 \%$ wanted to study by discussion.

\section{b) Teacher's Role}

The teaching and learning process, most of the students liked if the teacher giving materials through group Facebook.

There were $42.3 \%$ of the students liked to have more explanation when they have difficulties in writing activity.

\section{Discussion}

The data and information were derived from observe and research. The observe were made to got documents (syllabus and textbook). The researcher did the observation on june 11 in SMP Swasta Jambi Medan. The aim of this research was to develop appropriate writing materials for the students of the eighth grade of SMP Swasta Jambi Medan. The research was conducted in SMP Swasta Jambi Medan. The population sample of this research was 26 students of eighth grade.

The results of the student questionnaire showed that all students choose Facebook as the media for teaching to make it more interesting and the material could be read and studied repeatedly. This means that Facebook is already known by students. Regarding their opinion about writing descriptive text material, there were 28 students (53\%) who stated that the material was difficult. In addition, learning resources to write descriptive texts are only from teachers and textbooks.

In developing materials, there are several steps to develop them. Those were conducting need analysis, writing course grids, making the first draft of the materials, getting expert judgment and making the final product. 
The first step before developing the materials was conducting the needs analysis. The data of the needs analysis were obtained by distributing questionnaires to the students of eighth grade. The aim of this step was to find out the target needs and the learning needs. The needs analysis questionnaires were developed according to Hutchinson and Waters (in Haryanti, 2016) and Nunan (2004).

The next step was writing the materials. In the developed materials, the unit was conducted in four stages, those were Pre-Writing, Drafting, Responding and Editing. In Pre-Writing, students were provided a text, generic structure of the text and grammar. In Drafting, try to write their first draft of the text. In Responding, students' writing gets a feedback from the teacher or peers. In Editing, students edit their writing. The materials also include reflection, the summary of the unit and my dictionary (Words' list).

The next step after the materials developed was the expert judgment. Based on research results, the writing materials for students of the eighth grade that has been developed was appropriate with the students' target needs and learning need. With reference to expert validation, researchers make revisions and produce the final product. where the final product is uploaded through Facebook group.

\section{CONCLUSION AND SUGGESTION}

\section{Conclusion}

a) The result of the students questionnaire showed that all the students are familiar with facebook It means that facebook has already known by all students. Dealing with their opinion about the writing descriptive text materials is difficult, and students stated that their difficulty in writing was using correct and appropriate grammar. The source of learning writing descriptive text are only from their teacher and the text book and though the teacher sometimes using computer and LCD as the media to teach, but the teacher did not present the materials through those media rather pictures and films.

b) Developing Materials, was combined by some activities. The activities were started by adapting some texts from existing materials / text books and articles in the internet. The next process is competent expert validation on the developed draft product (the syllabus, lesson plan and my cute pat materials through facebook) as the result in developing the materials. By referring to the validation forms of the expert, the researcher did a revision and produced the final product.

\section{Suggestion}

\section{The English Teachers}


It is better if in the teaching and learning process of class VIII SMP English teachers using media that can involve students to encourage students to be motivated in learning. One of them is that the teacher can use FB media to teach students about writing descriptive text.

\section{The Other Material Developers}

The most important thing in developing material is analyzing student needs. Research products must meet the needs and interests of students. In addition, the material being taught must choose the right and varied media. This media can involve students in motivating and improving their abilities.

\section{References}

Alika, N.L.P., et all. 2016. Developing Writing Skill of The Eight Grade Students Through Listing Technique. e-Journal of English Language Teaching Society, Vol.4.No.2, 1-2.

Basonggo, Harni, et all. 2016. Developing Writing Skill of Grade VIII Students Through Personal Letter. e-Journal of English Language Teaching Society, Vol 4. No.1, 1. 2-29.

Brown, D. H. 2000. Teaching by Principles An Interactive Approach to Language Pedagogy. California: Longman.

Haryanti, P. A., 2016." Developing Writing Materials For Students Of The Eighth Grade Of SMP N 3 Tempel". Thesis. Faculty of Languages and Arts. English Language Education. Yogyakarta State University. Yogyakarta

Hastini, et all. 2018. Developing Skill In Writing Recount Text Through Free Writing. E-Journal of English Language Teaching Society. Vol. 6. No. 4. Retrieved from http://jurnal.untad.ac.id/jurnal/index.php/ELTS/article/ download/ 11535/8869.

Richards, J.C., and Renandya, W. A. 2002. Methodology in language teaching. New York: Cambridge University Press

Sutanta, E. 2014. Konsep dan Implementasi E-Learning. Downloaded from https://www.researchgate.net/publication/228343752.

Tomlinson, B. 2013. Developing Materials for Language Teaching. New York: Bloomsbury Academic. 